\title{
Antibacterial efficacy of Moringa oleifera leaf extract against pyogenic bacteria isolated from a dromedary camel (Camelus dromedarius) abscess
}

\author{
Ehab Ali Fouad, Azza S. M. Abu Elnaga and Mai M. Kandil
}

\author{
Department of Microbiology and Immunology, National Research Centre, Egypt. \\ Corresponding author: Ehab Ali Fouad, e-mail: ehabfoaud@gmail.com \\ Co-authors: ASMA: azzaabuelnaga@yahoo.com, MMK: mai.kandil@hotmail.com \\ Received: 16-12-2018, Accepted: 04-04-2019, Published online: 14-06-2019
}

doi: 10.14202/vetworld.2019.802-808 How to cite this article: Fouad EA, Abu Elnaga ASM, Kandil MM (2019) Antibacterial efficacy of Moringa oleifera leaf extract against pyogenic bacteria isolated from a dromedary camel (Camelus dromedarius) abscess, Veterinary World, 12(6): 802-808.

\begin{abstract}
Background: Abscess in camel is one of the most important bacterial infections. It causes anemia and emaciation, resulting in an economic loss due to carcass condemnation and a decrease in reproductive and production efficiency.

Aim: This investigation aimed to isolate the bacteria from abscesses in camels and evaluate the antibacterial activity of Moringa oleifera extracts.

Materials and Methods: Disk diffusion method and minimum inhibitory concentration were used for the evaluation of the antibacterial activity of $M$. oleifera extracts against isolated bacteria from camel abscesses.

Results: The isolated bacteria were displayed relatively as follows: Corynebacterium pseudotuberculosis (30.4\%), Staphylococcus aureus (25.8\%), Escherichia coli (17.8\%), Corynebacterium ulcerans (10.5\%), Klebsiella pneumoniae (8.5\%), Pseudomonas aeruginosa (8.5\%), Micrococcus spp. (6.7\%), Proteus vulgaris (5.2\%), Citrobacter spp. (4.2\%), and Staphylococcus epidermidis (1.7\%). The drugs of choice for Corynebacterium isolates were ciprofloxacin and trimethoprim/ sulfamethoxazole, whereas amikacin, ciprofloxacin, gentamicin, neomycin, novobiocin, streptomycin, and vancomycin were for Staphylococcus isolates. Moreover, the ethanol extracts of $M$. oleifera showed higher antibacterial efficacy than the cold aqueous extracts.
\end{abstract}

Conclusion: $M$. oleifera is considered one of the new infection-fighting strategies in controlling pyogenic bacteria responsible for camel abscesses.

Keywords: antibacterial activity, camel abscess, Moringa oleifera, pyogenic bacteria.

\section{Introduction}

In the past, researchers paid only a little attention to camel research. However, numerous bacterial, viral, and parasitic diseases have been recorded. Camel abscesses have received little attention with the bulk of research directed toward historic diseases of the camel. In addition, in abscesses, there are both economic and public health hazards, which generally result in economic losses due to the condemnation of infected carcasses or part of it, leading to nutritional problems [1]. Camels' breeding could be done to overcome Egyptian's needs for animal protein [2]. Certain breeds of camel can live in more humid environments; the major breed is the dromedary of the Nile Delta of Egypt [3].

There are few literatures on camel research, consequently, no recent data related to economic losses

Copyright: Fouad, et al. Open Access. This article is distributed under the terms of the Creative Commons Attribution 4.0 International License (http://creativecommons.org/licenses/by/4.0/), which permits unrestricted use, distribution, and reproduction in any medium, provided you give appropriate credit to the original author(s) and the source, provide a link to the Creative Commons license, and indicate if changes were made. The Creative Commons Public Domain Dedication waiver (http://creativecommons.org/ publicdomain/zero/1.0/) applies to the data made available in this article, unless otherwise stated. due to abscesses. However, abscesses in animals cause tremendous economic losses such as decreased production of animal meat, skin, and wool. Animals with abscess become anemic and emaciated, due to toxins produced from it, resulting in loss of the animal's value and decrease in its reproductive and productive efficiency [4-6]. Infected animals had a poor physical condition, decreased fertility and condemnation of carcasses totally or partially at abattoirs $[1,7,8]$.

Camel infections due to pyogenic bacteria such as Corynebacterium pseudotuberculosis, Corynebacterium pyogenes, Streptococci spp., Staphylococci spp., Corynebacterium ulcerans, Rhodococcus, Escherichia coli, Citrobacter spp., Klebsiellapneumoniae,Proteus spp., and Pseudomonas aeruginosa have been commonly reported in many areas [8-10]. In dromedaries, cervical and sciatic lymph nodes were mainly affected. Lymphangitis and suppurative lymphadenitis have been recorded in camel abscesses $[11,12]$. Camel abscess results in the entrance of the causative organism through the damaged skin and mucous membrane ended by reaching the regional lymph node then causes inflammatory and necrotic changes [13]. 
Moringa species is used in the medicinal field worldwide due to its pharmacological activities and considerable medicinal compounds. The most common species of Moringa genus is Moringa oleifera which has rich sources of various phytochemical compounds including glucosinolates and has antibacterial activity [14]. According to the World Health Organization, $80 \%$ of the populations in developing countries prefer to use herbal extract and their active components as traditional medicine therapy[4]. M. oleifera is commonly known as drumstick and has many active components such as alkaloids, tannins, flavonoids, saponins, and triterpenoids $[15,16]$ with potent anthelmintic activity [17] and antibacterial effect [18]. The phytochemical analysis of $M$. oleifera showed its bioactive compounds $[19,20]$ with their pharmacological activity [21]. M. oleifera has a broad safety margin for human and animal consumption [22]. Disk diffusion method was used for the evaluation of the antibacterial activity of Moringa extracts, and the significant difference of inhibition zones appeared. P. aeruginosa, Enterococcus faecalis, and Staphylococcus aureus were used to assess the antibacterial effect of the extract $[18,23]$.

This investigation aimed to isolate the bacteria from abscesses in camels and evaluate the antibacterial activity of $M$. oleifera extracts.

\section{Materials and Methods}

\section{Ethical approval}

The study was performed according to the Guide for the care and use of Laboratory animals and Ethical Approval of Animal Rights according to Committee, National Research Centre, Egypt.

\section{Sampling}

One hundred and seventy pus swabs were collected from 30 living and 70 slaughtered male camels (7-9 years old) that were obtained from El-Monib abattoir, Giza. These samples were obtained from external abscesses involving superficial lymph nodes and subcutaneous tissue, especially at the head, neck, and shoulder regions. Internal abscesses were mainly seen in the lungs, liver, and bronchial lymph nodes. According to Hatem et al. [5], the swabs placed in ice bags were transported through Cary-Blair (Difco) transport medium to the Department of Microbiology and Immunology, Veterinary Division, National Research Centre (NRC).

The collected swab samples were streaked onto blood agar plates (nutrient agar $13 \mathrm{~g} / \mathrm{L}$ containing $5 \%$ citrated sheep blood), MacConkey agar plates $(52 \mathrm{~g} / \mathrm{L})$, and mannitol salt agar $7.5 \%$ plates $(111 \mathrm{~g} / \mathrm{L})$. All samples were streaked in duplicate plates and were incubated aerobically and anaerobically at $37^{\circ} \mathrm{C}$ for $24 \mathrm{~h}$ and $37^{\circ} \mathrm{C}$ for $48-72 \mathrm{~h}$, respectively.

\section{Identification of bacterial isolates}

Bacterial isolates were microscopically identified according to Cruickshank et al. [24]. Biochemical identification of Gram-positive coccobacilli was carried out according to Funk et al. [25]. Biochemical identification of Gram-positive cocci and Gram-negative bacteria was carried out according to Quinn et al. [26] and Cruickshank et al., respectively [24].

\section{Antibiotic sensitivity test for identified strains}

Fifteen standard antibiotic disks were used against the isolated bacteria after preparation of the standardized bacterial inoculums matching with $0.5 \mathrm{McFarland}$ tubes $\left(10^{8}\right.$ colony-forming unit $[\mathrm{CFU}] / \mathrm{ml})$. Then, $25 \mu \mathrm{l}$ of the inoculum was distributed on Muller-Hinton agar plates and incubated at $37^{\circ} \mathrm{C}$ for $24 \mathrm{~h}$. The degree of sensitivity was determined by measuring the inhibition zone. The result was interpreted according to Dzotam et al. [16].

\section{Plant material of M. oleifera}

Moringa leaf powder was obtained from Moringa Unit, NRC. It was collected from a farm of the NRC in Al-Nubaria which is situated along Cairo/ Alexandria desert road. The plant material was collected in January 2018 and presented in the study.

\section{Cold aqueous extracts of $M$. oleifera leaves}

$100 \mathrm{~g}$ of $M$. oleifera leaf powder was weighed out and dissolved in $400 \mathrm{ml}$ of cold distilled water into a conical flask stoppered with rubber corks and left for 7 days with occasional shaking (10 times/day). The mixture was filtered off using a sterile filter paper (Whatman no. 1) into a clean conical flask and subjected to water bath evaporation where the aqueous solvent was evaporated at its boiling temperature of $100^{\circ} \mathrm{C}$. The standard extracts obtained were then stored in a refrigerator at $4^{\circ} \mathrm{C}$ for antibacterial activity test [27].

\section{Hot aqueous extracts of $M$. oleifera leaves}

The same protocol as in cold water treatment was used with 30 min of boiling while the plant material was dipped in distilled water.

\section{Ethanol ( $95 \%$ ) extracts of $M$. oleifera leaves}

Here, the same procedure as in cold water treatment was followed.

\section{Test microorganisms}

All the isolated bacteria from camel abscesses were used to assess the antibacterial effect of $M$. oleifera. It included C. pseudotuberculosis, C. ulcerans, and $S$. aureus as Gram-positive bacteria and E. coli, K. pneumoniae, Citrobacter spp., Proteus vulgaris, and $P$. aeruginosa as Gram-negative bacteria.

\section{Antibacterial assay of M. oleifera}

The antibacterial activity of the three different samples, namely, (1) cold water extract (CWE) of leaves, (2) hot water extract of leaves, and (3) ethanol extracts (EEs) of leaves, was individually tested against the studied bacteria. In vitro antibacterial test was then carried out by disk diffusion method [28,29] using $25 \mu$ of the standardized bacterial suspension of the tested bacteria $\left(10^{8} \mathrm{CFU} / \mathrm{ml}\right)$ spread on plates. The disks ( $6 \mathrm{~mm}$ in diameter) were impregnated for different samples with $10 \mu \mathrm{l}$ of $0.1 \mathrm{~g} / \mathrm{ml}(100 \mathrm{mg} /$ disk $)$, followed by air drying, and were placed on seeded agar 
plates. Negative controls were prepared using the same solvents to dissolve the plant extracts. Tetracycline (TE) $(30 \mu \mathrm{g} /$ disk $)$ was used as a positive control to determine the sensitivity of bacterial strain. The plates were incubated at $37^{\circ} \mathrm{C}$ for $24 \mathrm{~h}$. The antimicrobial activity was evaluated by measuring the zones of inhibition against the tested bacteria.

\section{Minimum inhibitory concentration (MIC)}

The MIC of different samples of M. oleifera was determined by two-fold serial dilution method [14]. Serial dilution of $100 \mathrm{mg} / \mathrm{ml}$ for rest of the samples were separately done to achieve $50,25,12.50,6.25$, $3.12,1.56,0.78 \mathrm{mg} / \mathrm{ml}$ and $390,195,97 \mu \mathrm{g} / \mathrm{ml}$ concentration were used for MIC determination. Briefly, $100 \mu \mathrm{l}$ of varying concentrations of samples were added into the test tubes separately, containing $9 \mathrm{ml}$ of the standardized suspension of tested bacteria $\left(10^{8} \mathrm{CFU} / \mathrm{ml}\right)$. The test tubes were incubated at $37^{\circ} \mathrm{C}$ for $24 \mathrm{~h}$. Controls were used with the test organisms, using distilled water instead of the plant extract. The least concentration of the samples with no visible growth was taken as the MIC [30].

\section{Statistical analysis}

To evaluate associations between variables (antibiotic profiles), the data were analyzed statistically using Student's " $t$-" test, showing mean + standard deviation [31].

\section{Results}

The isolated bacteria were displayed relatively as follows: C. pseudotuberculosis (30.4\%), S. aureus (25.8\%), E. coli (17.8\%), C. ulcerans (10.5\%), K. pneumoniae (8.5\%), P. aeruginosa (8.5\%), Micrococcus spp. (6.7\%), P. vulgaris $(5.2 \%)$, Citrobacter spp. (4.2\%), and Staphylococcus epidermidis (1.7\%). These bacteria obtained from 170 pus swabs were collected from 30 living and 70 slaughtered male camels (7-9 years old) that were obtained from El-Monib abattoir, Giza.
Corynebacterium spp. colonies were appeared smooth, white in color, opaque, flat, circular, and small in size. Moreover, they had a narrow zone of $\beta$-hemolysis on blood agar. The biochemical characteristics of C. pseudotuberculosis were positive catalase, urease, glucose, maltose fermentation and negative starch and trehalose fermentation, negative gelatin liquefaction, and nitrate reduction. C. ulcerans exhibited positive catalase, urease, gelatin liquefaction and fermented glucose, maltose, starch, and trehalose, with negative nitrate reduction test. On the other hand, Gram-positive cocci on nutrient agar was golden yellow in color; was smooth, opaque, circular, and medium in size; and was surrounded by the zone of $\beta$-hemolysis on blood agar but was yellow in color on mannitol salt agar. While the non-hemolytic white colonies on blood agar exhibited pink colonies on mannitol salt agar. S. aureus was biochemically identified by catalase and coagulase positive, fermented maltose, trehalose, mannitol, and sucrose. While, S. epidermidis was coagulase negative, catalase positive and fermented sucrose only. Micrococcus isolates showed catalase positivity, coagulase negativity, and oxidative reaction $(\mathrm{O})$ in the $\mathrm{O} / \mathrm{F}$ test. Moreover, the Gram-negative bacilli were smooth, flat, circular and medium-sized colonies; either lactose fermenter colonies (appeared pink on MacConkey agar) or non-lactose fermenter (colorless). The biochemical characteristics of the isolated Gram-negative bacteria revealed the isolation of $E$. coli $(17.8 \%), P$. aeruginosa (8.5\%), K. pneumoniae (8.5\%), P. vulgaris (5.2\%), and Citrobacter spp. (4.2\%). The antibiotic sensitivity test is shown in Table-1.

\section{Antibacterial activity of $M$. oleifera extracts}

The antibacterial activity of cold water, hot water, and EE of M. oleifera is shown in Table-2. The EE of the leaves displayed a pronounceable better antibacterial effect against all the tested $C$. pseudotuberculosis, $C$. ulcerans, S. aureus, E. coli, K. pneumoniae, Citrobacter

Table-1: Antibiogram of reference drugs against bacterial isolates from camel abscesses.

\begin{tabular}{|c|c|c|c|c|c|c|}
\hline \multirow[t]{3}{*}{ Antibiotic } & \multicolumn{6}{|c|}{ Bacteria } \\
\hline & \multicolumn{2}{|c|}{ Corynebacterium (\%) } & \multicolumn{2}{|c|}{ Staphylococcus (\%) } & \multicolumn{2}{|c|}{ Gram-negative bacteria (\%) } \\
\hline & Sensitive & Resistant & Sensitive & Resistant & Sensitive & Resistant \\
\hline Amikacin & 85 & & 100 & - & 95 & - \\
\hline Ampicillin & $*$ & 94 & - & * & $*$ & - \\
\hline Augmentin & $*$ & 91 & - & * & $*$ & - \\
\hline Ciprofloxacin & 100 & - & 100 & - & 100 & - \\
\hline Gentamicin & 86 & - & 100 & - & - & 90 \\
\hline Erythromycin & $*$ & 92 & - & $*$ & - & - \\
\hline Metronidazole & - & 87 & - & 70 & - & 100 \\
\hline Neomycin & 80 & - & 100 & - & $*$ & \\
\hline Novobiocin & 85 & - & 100 & - & 80 & - \\
\hline Penicillin G & & 90 & 65 & - & $*$ & - \\
\hline Rifampicin & & 79 & 86 & - & - & 82 \\
\hline Streptomycin & 96 & - & 100 & - & 100 & - \\
\hline Trimethoprim/sulfamethoxazole & 100 & - & 96 & - & 100 & - \\
\hline Vancomycin & - & 100 & 100 & - & - & 100 \\
\hline Tetracycline & 80 & - & 78 & - & 90 & - \\
\hline
\end{tabular}

$\%=$ Was calculated according to the number of examined samples. *Intermediate zone of inhibition 
spp., $P$. vulgaris, and $P$. aeruginosa and their corresponding inhibition zone diameters were $25.65 \pm 0.04$, $30.5 \pm 0.28, \quad 26.75 \pm 0.04, \quad 27.75 \pm 0.04, \quad 28.5 \pm 0.3$, $20.85 \pm 0.05,24.75 \pm 0.12$, and $22.25 \pm 0.04$, respectively. The CWE of leaves showed relatively obvious antibacterial effect against $C$. pseudotuberculosis, C. ulcerans, S. aureus, E. coli, K. pneumoniae, Citrobacter spp., $P$. vulgaris, and $P$. aeruginosa with their individual diameter zones of inhibition recorded at $22.5 \pm 0.04$, $25.5 \pm 0.12, \quad 14.75 \pm 0.05, \quad 18.25 \pm 0.28, \quad 21.75 \pm 0.04$, $20.65 \pm 0.13,14.75 \pm 0.04$, and $17.5 \pm 0.04$, respectively. However, no inhibitory action was determined for hot water extract. The TE antibiotic was used as a positive control in comparison of Moringa extracts' activity. The results showed the high antibacterial activity of ethanol and CWEs compared to the activity of TE.

Table-3 shows the MIC of the extracts from M. oleifera. MIC values of EEs ranged from 390 to $780 \mu \mathrm{g} / \mathrm{ml}$, whereas the MIC values of the aqueous extracts ranged from 25 to $50 \mathrm{mg} / \mathrm{ml}$. In this study, the lowest MIC value was exhibited by EEs at $390 \mu \mathrm{g} / \mathrm{ml}$.

\section{Discussion}

M. oleifera is considered one of the new infection-fighting strategies in controlling pyogenic bacteria responsible for camel abscesses.

Improvement of camels' health and breed should be kept in mind for the economic significance of camel meat and milk. [2]. The appearance of abscesses in camel creates a marketing problem due to the decline of the meat quality and quantity and condemnation of the affected portions and internal organs. Isolation of Corynebacterium species, $S$. aureus, Streptococci, Rhodococcus, E. coli, K. pneumoniae, Citrobacter spp., $P$. vulgaris, and $P$. aeruginosa from lymphadenitis and abscesses in camels had been reported in the literature [1, 8-12].

The present work focuses on the isolation and identification of bacteria causing abscess in camel. The results of the survey on the prevalence of abscesses in camels resulted in the isolation of $C$. pseudotuberculosis $(30.4 \%)$, S. aureus $(25.8 \%)$, E. coli $(17.8 \%)$, C. ulcerans (10.5\%), P. aeruginosa (8.5\%), K. pneumoniae (8.5\%), Micrococcus spp. (6.7\%), P. vulgaris (5.2\%), Citrobacter spp. (4.2\%), and S. epidermidis (1.7\%). C. pseudotuberculosis was the highest isolated one followed by $S$. aureus and E. coli. These organisms were previously reported as a cause of camel abscess by Wernery [6], Hassan et al. [7], Wernery [8], Berlin [11], and Wernery and Kinne [12]. The Gramnegative bacteria did not isolate alone in an abscess, but they were associated with Corynebacterium spp. and/or Staphylococcus spp. Further investigations are needed to know if they can induce abscess alone or they come as a secondary infection.

An antibiogram study was assessed on all isolates; Table-1 clearly indicates that ciprofloxacin (100\%), trimethoprim/sulfamethoxazole (100\%), streptomycin

Table-2: Antibacterial activity of Moringa oleifera extracts against some pyogenic bacteria.

\begin{tabular}{|c|c|c|c|c|}
\hline \multirow[t]{2}{*}{ Bacteria } & \multicolumn{4}{|c|}{ Zone of inhibition (mm) } \\
\hline & $\begin{array}{c}\text { Cold water } \\
\text { extract }\end{array}$ & $\begin{array}{l}\text { Hot water } \\
\text { extract }\end{array}$ & $\begin{array}{l}\text { Ethanol } \\
\text { extract }\end{array}$ & $\begin{array}{c}\text { Positive control } \\
\text { tetracycline }\end{array}$ \\
\hline \multicolumn{5}{|l|}{ Gram-positive } \\
\hline Corynebacterium pseudotuberculosis & $22.5 \pm 0.04$ & + & $25.65 \pm 0.04$ & $18.3 \pm 0.12$ \\
\hline Corynebacterium ulcerans & $25.5 \pm 0.12$ & + & $30.5 \pm 0.28$ & $20.16 \pm 0.19$ \\
\hline Staphylococcus aureus & $14.75 \pm 0.05$ & + & $26.75 \pm 0.04$ & $17.20 \pm 0.13$ \\
\hline \multicolumn{5}{|l|}{ Gram-negative } \\
\hline Escherichia coli & $18.25 \pm 0.28$ & + & $27.75 \pm 0.04$ & $20.16 \pm 0.43$ \\
\hline Klebsiella pneumoniae & $21.75 \pm 0.04$ & + & $28.5 \pm 0.3$ & $16.75 \pm 0.08$ \\
\hline Citrobacter spp. & $20.65 \pm 0.13$ & + & $19.5 \pm 0.05$ & $22.65 \pm 0.12$ \\
\hline Proteus vulgaris & $14.75 \pm 0.04$ & + & $24.75 \pm 0.12$ & $19.2 \pm 0.04$ \\
\hline Pseudomonas aeruginosa & $17.5 \pm 0.04$ & + & $22.25 \pm 0.04$ & $16.75 \pm 0.08$ \\
\hline
\end{tabular}

Values are presented as mean \pm S.E of triplicate experiments. $+=$ Growth

Table-3: MIC values of Moringa oleifera extract against some pyogenic bacteria.

\begin{tabular}{|c|c|c|c|}
\hline \multirow[t]{2}{*}{ Bacteria } & \multicolumn{3}{|c|}{ MIC } \\
\hline & Cold water extract $\mathbf{m g} / \mathrm{ml}$ & Hot water extract & Ethanol extract $\mu \mathrm{g} / \mathrm{ml}$ \\
\hline \multicolumn{4}{|l|}{ Gram-positive } \\
\hline Corynebacterium pseudotuberculosis & 25 & nd & 390 \\
\hline Corynebacterium ulcerans & 25 & nd & 390 \\
\hline Staphylococcus aureus & 50 & nd & 390 \\
\hline \multicolumn{4}{|l|}{ Gram-negative } \\
\hline Escherichia coli & 25 & nd & 390 \\
\hline Klebsiella pneumoniae & 50 & nd & 780 \\
\hline Citrobacter spp. & 50 & nd & 390 \\
\hline Proteus vulgaris & 25 & nd & 780 \\
\hline Pseudomonas aeruginosa & 25 & nd & 780 \\
\hline
\end{tabular}

nd=No detection, MIC=Minimum inhibitory concentration 


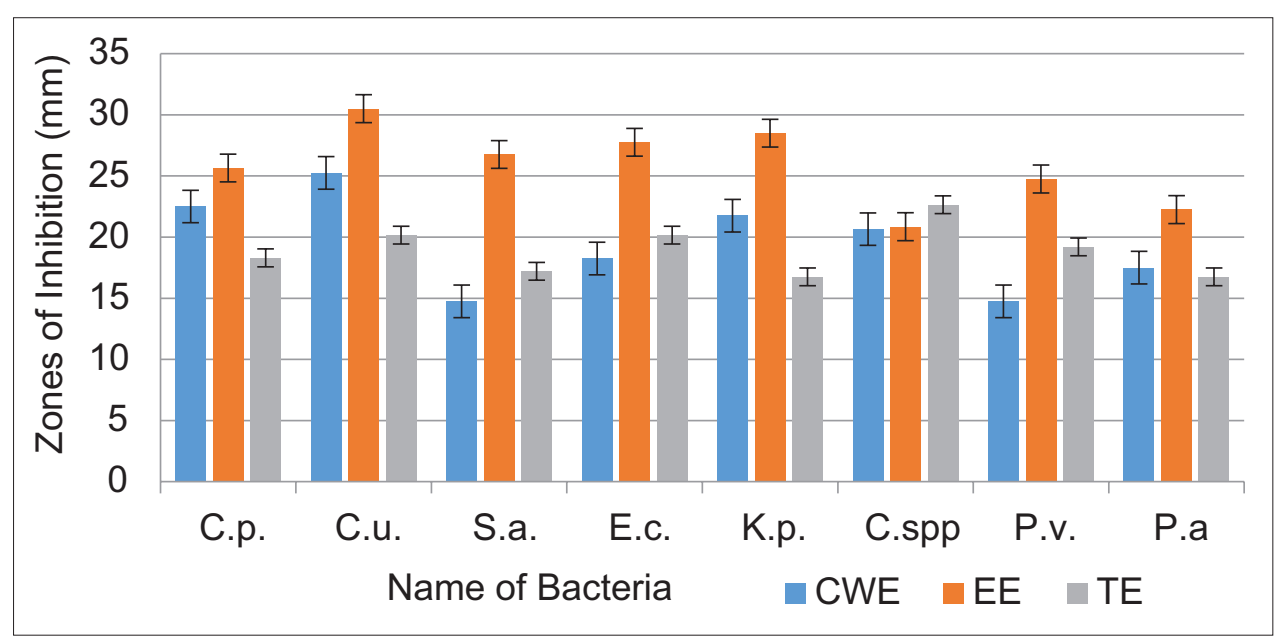

Figure-1: Moringa oleifera extracts and tetracycline antibiotic effect on some pyogenic bacteria. CWE=Cold water extract, $\mathrm{EE}=$ Ethanol extract, $\mathrm{TE}=$ Tetracycline, C.p.=Corynebacterium pseudotuberculosis, C.u.=Corynebacterium ulcerans, $\mathrm{S} . \mathrm{a}=$ Staphylococcus aureus, E.C.=Escherichia coli, K.p.=Klebsiella pneumoniae, C.spp.=Citrobacter spp., P.v.=Proteus vulgaris and, P.a=Pseudomonas aeruginosa.

$(96 \%)$, amikacin $(85 \%)$, neomycin $(80 \%)$, gentamicin $(86 \%)$, TE $(80 \%)$, and novobiocin $(85 \%)$ were sensitive. Whereas vancomycin $(100 \%)$, penicillin $\mathrm{G}$ $(90 \%)$, metronidazole $(87 \%)$, and rifampicin $(79 \%)$ were resistant for the isolated Corynebacterium. This agrees with the finding of Hatem et al. [5], Hassan et al. [7], Muckle and Gyles [32], Judson and Songer [33], Zhao et al. [34], and Mohan et al. [35]. Table-1 indicates that vancomycin (100\%), ciprofloxacin $(100 \%)$, amikacin $(100 \%)$, neomycin $(100 \%)$, gentamicin (100\%), streptomycin (100\%), novobiocin $(100 \%)$, trimethoprim/sulfamethoxazole $(96 \%)$, rifampicin (86\%), penicillin G (65\%), and TE (78\%) were sensitive to Staphylococcus isolates. This agrees with the finding of Hatem et al. [5], Lowy [36], Moran et al. [37], and Zhu et al. [38]. While Hatem et al. [5] recorded sensitivity to ampicillin $(94.29 \%)$, augmentin $(91.43 \%)$, and erythromycin $(91.43 \%)$, this result disagrees with of the Staphylococcus isolates, as they were resistant to metronidazole, ampicillin, augmentin, and erythromycin. However, Guler et al., Udo et al., and Virdis et al. [39-41] illustrated the reason for lack of antibiotic susceptibility of Staphylococcus due to the multidrug-resistant genes acquired by bacteria. The multidrug-resistant strains of bacteria should be faced by new infection-fighting strategies $[42,43]$.

The present investigation illustrated that the disk diffusion method was used for the evaluation of the antibacterial activity of $M$. oleifera extracts. The EEs showed higher antibacterial effect than the cold aqueous extracts (Figure-1). Hence, the extraction process with an organic solvent such as ethanol provided a better antibacterial activity than the processes of soaking, obtaining decoction, and boiling of the plant in water, which agrees with the finding of Nair et al. [44]. In this investigation, the greatest inhibition zones were found in EE against all the bacteria tested, which were higher than that of antibiotic TE (30 $\mu \mathrm{g} /$ disk) (Figure-1). In earlier studies, researchers reported that plant extracts showed less antibacterial effect on bacteria $[45,46]$. The pharmacological activities and considerable medicinal compounds of M. oleifera have high antibacterial effect when compared to the broad-spectrum TE antibiotic $[30,47]$. Today, most bacteria are multidrug-resistant [5,48-51]. Natural antioxidants such as ascorbic acid, flavonoids, phenolics, and carotenoids are obtained from Moringa leaves [52]. It was reported that they have novel active compounds which possess an antibacterial effect and can overcome the multidrug resistance problem $[16,53]$. Hence, M. oleifera is considered one of the new infection-fighting strategies in controlling multi-drug resistant pathogenic bacteria. As well as, it has a wide safety margin for human and animal consumption.

\section{Conclusion}

In the current study, it can be concluded that the most predominant pyogenic bacteria isolated from camel abscesses were C. pseudotuberculosis, $S$. aureus, and E. coli. An effective infection control program is needed with a highly effective antibacterial agent/s because antibiotic resistance is common in Egyptian isolates. The bactericidal effect of $M$. oleifera leaf extracts was determined against the isolated bacteria. It further discusses optimal conditions for the extraction of essential compounds responsible for the elimination of pathogenic bacteria.

\section{Authors' Contributions}

EAF was involved in the disease investigation in the field, planning, sampling, bacterial isolation, and mainly participated in the practical part and writing of the manuscript; ASMA and MMK revised the results, microbiological analysis, and manuscript. All authors wrote, read, and approved the final manuscript.

\section{Acknowledgments}

The authors are thankful to National Research Center, Egypt for providing facilities. The authors did not receive any fund for this study. 


\section{Competing Interests} interests

The authors declare that they have no competing

\section{Publisher's Note}

Veterinary World remains neutral with regard to jurisdictional claims in published institutional affiliation.

\section{References}

1. Ranjan, R., Vyas, S., Kashinath, S., Sonawane, G. and Patil, N.V.(2018)Lymphadenitis caused by Corynebacterium pseudotuberculosis in a dromedary (Camelus dromedarius) Herd. J. Camel Pract. Res., 25(1): 45-53.

2. Abdel-Rahman, E.H., El-Jakee, J.K., Hatem, M.E., Ata, N.S. and Fouad, E.A. (2017) Preparation of goat and rabbit anticamel immunoglobulin $\mathrm{G}$ whole molecule labeled with horseradish peroxidase. Vet. World, 10(1): 92-100.

3. Nawito, M.F., Shalash, M.R., Hoppe, R. and Rakha, A.M. (1967) Reproduction in female camel. Nat. Res. Cent. Bull., 2(2): 82

4. Alhakmani, F., Kumar, S. and Khan, S.A. (2013) Estimation of total phenolic content, in vitro antioxidant and anti-inflammatory activity of flowers of Moringa oleifera. Asian Pac. J. Trop. Biomed., 3(8): 623-627.

5. Hatem, M.E., Arab, R.H., Ata, S.N., El-Moez, S.I.A., Khairy, E.A. and Fouad, E.A. (2013) Bacterial Abscessationin in sheep and goat in Giza governorate with full antibiogram screening. Glob. Vet., 10(4): 372-381.

6. Wernery, U. (2015) Production of a caseous lymphadenitis vaccine for dromedaries. J. Camel Pract. Res., 22(2): 163-168.

7. Hassan, N.A., Al-Humiany, A.A., Bahoboil, A.S. and Mansour, A.M.A. (2011) Bacteriological and pathological studies on caseous lymphadenitis in sheep in Saudi Arabia. Int. J. Microbiol. Res., 2(1): 28-37.

8. Wernery, U. (2012) Caseous lymphadenitis (pseudotuberculosis) in camelids. J. Camel Pract. Res., 19(1): 21-27.

9. Yagoub, S.O. (2005) Bacterial disease of the reproductive system of camel (Camelus dromedarius) in Eastern Sudan. J. Anim. Vet. Adv., 4(7): 642-644.

10. Zidan, K.H., Mazloum, K., Saran, M.A. and Hatem, M.E. (2013) Abscesses in Dromedary Camels, Sheep and Goats Etiology and Pathology. $1^{\text {st }}$ International Scientific Conference of Pathology Department, Faculty of Veterinary Medicine. p 47-59.

11. Berlin, M. (2015) Corynebacterium pseudotuberculosis bei Kamelen-Epidemiologie undPhasen der Impfstoffherstellung. Bachelor of Science Thesis (B. Sc.) Beuth Hochschule für Technik. Berlin-University of Applied Science, Berlin. p 1-43.

12. Wernery, U. and Kinne, J. (2016) Caseous lymphadenitis (pseudotuberculosis) in camelids: A review. Austin J. Vet. Sci. Anim. Husbandry, 3(1): 1022-1028.

13. Sahoo, S. and Ganguly, S. (2015) Surgical management of abscess in camel: A case report. World J. Biol. Med. Sci., 2(4): 32-34.

14. Mgbeahuruike, A.C., Edeh, G., Eze, C.S., Parker, J., Ekere, S.O., Kanu, O.O. and Dibua, E. (2017) Comparative evaluation of the antimicrobial profile of Moringa leaf and seed oil extracts against resistant strains of wound pathogens in orthopedic hospitals. Afr. J. Microbiol. Res., 11(39): 1484-1494.

15. Wansi, J.D., Devkota, K.P., Tshikalange, E. and Kuete, V. (2013) 14-alkaloids from the medicinal plants of Africa. In: Kuete V, editor. Medicinal Plant Research in Africa. Elsevier, Oxford. p 557-605.

16. Dzotam, J.K., Touani, F.K. and Kuete, V. (2016)Antibacterial and antibiotic-modifying activities of three food plants (Xanthosoma mafaffa Lam., Moringa oleifera (L.) Schott and Passiflora edulis Sims) against multidrug-resistant (MDR) Gram-negative bacteria. BMC Complement. Altern. Med., 16(9): 1-8.

17. Hegazi, A.G., Megeed, K.N.A., Hassan, S.E., Abdelaziz, M.M., Toaleb, N.I., El Shanawany, E.E. and Aboelsoued, D. (2018) Comparative ovicidal activity of Moringa oleifera leaf extracts on Fasciola gigantica eggs. Vet. World, 11(2): 215-220.

18. El-Kholy, K.H., Barakat, S.A., Morsy, W.A., AbdelMaboud, K., Seif-Elnaser, M.I. and Ghazal, M.N. (2018) Effect of aqueous extract of Moringa oleifera leaves on some production performance and microbial ecology of the gastrointestinal tract in growing rabbits. Pak. J. Nutr., 17(1): 1-7.

19. Isitua, C.C., Sanchez-Muros, M.J., Jaramillo, J.C.G. and Dutan, F. (2015) Phytochemical and nutritional properties of dried leaf powder of Moringa oleifera Lam. From Machala El Oro province of Ecuador. Asian J. Plant Sci. Res., 5(2): 8-16.

20. Vongsak, B., Mangmool, S. and Gritsanapan, W. (2015) Antioxidant activity and induction of mRNA expressions of antioxidant enzymes in HEK-293 cells of Moringa oleifera leaf extract. Planta Med. J., 81(12-13): 1084-1089.

21. Vats, S. and Gupta, T. (2017) Evaluation of bioactive compounds and antioxidant potential of hydroethanolic extract of Moringa oleifera Lam. From Rajasthan, India. Physiol. Mol. Biol. Plants, 23(1): 239-248.

22. Stohs, S.J. and Hartman, M.J. (2015) Review of the safety and efficacy of Moringa oleifera. Phytother. Res. J., 29(6): 796-804.

23. Makita, C. (2015) A Study of the Elemental Analysis and the Effect of the Pressurised Hot Water Extraction Method (PHWE) on the Antibacterial Activity of Moringa oleifera and Moringa ovalifolia Plant Parts. Available from: http://www.hdl.handle.net/10539/16828. Retreived on 06-06-2019.

24. Cruickshank, R., Duguid, B.P., Mien, M. and Swain, R.H.A. (1975) Medical Microbiology. 12 ${ }^{\text {th }}$ ed. Churchill Living Stone, Edinburgh, London and New York.

25. Funk, G., Graevenitz, A., Claride, J. and Bernard, K. (1997) Clinical microbiology of coryneform bacteria. Clin. Microbiol. Rev., 10(1): 125-159.

26. Quinn, P.J., Markey, B.K., Carter, M.E., Donnelly, W.J.C., Leonard, F.C. and Maguire, D. (2002) Veterinary Microbiology and Microbial Diseases. $1^{\text {st }}$ ed. Blackwell Science Ltd., Chichester, West Sussex, UK.

27. Rahman, M.M., Sheikh, M.I., Sharmin, S.A., Islam, M.S., Rahman, M.A., Rahman, M.M. and Alam, M.F. (2009) Antibacterial activity of leaf juice and extracts of Moringa oleifera Lam. Against some human pathogenic bacteria. CMU J. Nat. Sci., 8(2): 219-227.

28. Bauer, A.W., Kibry, W.M.M., Sherris, J.C. and Turck, M. (1966) Antibiotic susceptibility testing by a standardized single disk method. Am. J. Clin. Pathol., 45(4): 493-496.

29. Barry, A.L. (1980) Procedure for testing antimicrobial agent in agar media. In: Lorian, V., editor. Antibiotics in Laboratory Medicines. Williams and Wilkins Co., Baltimore. p 1-23.

30. Opara, A.U., Anyanwu, G. and Uloneme, G.C. (2015) The antibacterial action of Moringa oleifera on some wound and enteric pathogens. J. Med. Sci. Clin. Res., 3(7): 6741-6757.

31. Zar, J.H. (1999) Biostatistical Analysis. Prentice Hall, New Jersey, USA. p 663.

32. Muckle, C.A. and Gyles, C.L. (1982) Characterization of strains of Corynebacterium pseudotuberculosis. Can. J. Comp. Med., 46(2): 206-208.

33. Judson, R. and Songer, J.G. (1991) Corynebacterium pseudotuberculosis: In vitro susceptibility to 39 antimicrobial agents. Vet. Microbiol., 27(2): 145-150.

34. Zhao, H.K., Morimura, H., Hiramune, T., Kikuchi, N., Yanagawa, R. and Serikawa, S. (1991) Antimicrobial susceptibility of Corynebacterium pseudotuberculosis isolated from lesions of caseous lymphadenitis in sheep in 
Hokkaido, Japan. Vet. Med. Sci., 53(2): 355-356.

35. Mohan, P., Vathsala, M. and Jayaprakasan, V. (2007) Comparative characterization of C. pseudotuberculosis from goats in Kerala, India and reference strain. Small Rumin. Res., 74(1-3): 226-230.

36. Lowy, F.D. (2003) Antimicrobial resistance: The examples of Staphylococcus aureus. J. Clin. Invest., 111(9): 1265-1273.

37. Moran, G.J., Krishnadasan, A., Gorwitz, R.J., Rosheim, G.E., McDougal, L.K., Carey R.B. and Talan, D.A. (2006) Methicillin-resistant $S$. aureus infections among patients in the emergency department. N. Engl. J. Med., 355(7): 666-674.

38. Zhu, W., Clark, N.C., McDougal, L.K., Hageman, J., McDonald L.C. and Patel, J.B. (2008) Vancomycinresistant Staphylococcus aureus isolates associated with Inc18-like van a plasmids in Michigan. Antimicrob. Agents Chemother., 52(2): 452-457.

39. Guler, L., Ok, U., Gunduz, K., Gulcu, Y. and Hadimli, H.H. (2005) Antimicrobial susceptibility and coagulase genotyping of Staphylococcus aureus isolated from bovine clinical mastitis cases in Turkey. J. Dairy Sci., 88(9): 3149-3154.

40. Udo, E.E., L-Sweih, N.A., Dhar, R., Dimitrov, T.S., Mokddas, M.E., Johny, M., Al-Obaid, I.A., Gomaa, H.H., Mobasher, L.A., Rotimi, V.O. and Al-Asar, A.A. (2008) Surveillance of antibacterial resistance in Staphylococcus aureus isolated in Kuwaiti hospitals. Med. Princ. Pract., 17(1): 71-75.

41. Virdis, S., Scarano, C., Cassu, F., Spanu, V., Spanu C. and Santis, E.P.L. (2010) Antibiotic resistance in Staphylococcus aureus and coagulase-negative staphylococci isolated from goats with subclinical mastitis. Vet. Med. Int., 2010: 517060.

42. Djeussi, D.E., Noumedem, J.A., Seukep, J.A., Fankam, A.G., Voukeng, I.K. and Tankeo, S.B. (2013) Antibacterial activities of selected edible plants extract against multidrug-resistant gram-negative bacteria. BMC Complement. Altern. Med., 1310(13): 164.

43. Touani, F.K., Seukep, A.J., Djeussi, D.E., Fankam, A.G., Noumedem, J.A. and Kuete, V.(2014)Antibiotic-potentiation activities of four Cameroonian dietary plants against multidrug-resistant gram-negative bacteria expressing efflux pumps. BMC Complement. Altern. Med., 14(1): 258.

44. Nair, R., Kalariya, T. and Sumitra, C. (2005) Antibacterial activity of some selected Indian medicinal flora. Turk. $J$. Biol., 29(1): 41-47.

45. Kuhnt, M., Probstle, A., Rimpler, H., Bauer, R. and Heinrich, M. (1994) Biological and pharmacological activities and further constituents of Hyptis verticillata. Planta Med., 61(3): 227-232.

46. Afolayan, A.J. and Meyer, J.J. (1995) Antibacterial activity of Helichrysum aureonitens (Asteraceae) J. Ethnopharmacol., 47(2): 109-111.

47. Kansal, S.K. and Kumari, A. (2014) Potential of M. oleifera for the treatment of water and wastewater. Chem. Rev., 114(9): 4993-5010.

48. Dubreuil, J.D. (2013) Antibacterial and antidiarrheal activities of plant products against enterotoxigenic Escherichia coli. Toxins, 5(11): 2009-2041.

49. Fankam, A.G., Kuiate, J.R. and Kuete, V. (2014) Antibacterial activities of Beilschmiedia obscura and six other Cameroonian medicinal plants against multi-drug resistant gram-negative phenotypes. BMC Complement. Altern. Med., 14(1): 241.

50. Arafa, A.A., Ibrahim, E.S., Fouad, E.A. and Gaber, E.S. (2016) Antibiotic resistance of staphylococci concerning strains included in food industry in Egypt. Int. J. Pharm. Clin. Res., 8(12): 1583-1589.

51. Hegazi, A.G., Al Guthami, F.M., Al Gethami, A.F.M., Allah, F.M.A., Saleh, A.A. and Fouad, E.A. (2017) Potential antibacterial activity of some Saudi Arabia honey. Vet. World, 10(2): 233-237.

52. El-Gindy, Y.M., Zewell, H.S. and Hamad, M. (2017) Effect of Moringa leaf as a natural antioxidant on growth performance, blood lipid profile and immune response of rabbits under moderate heat stress. Egypt. J. Poult. Sci., 37(2): 333-344.

53. Isitua, C.C., Ibeh, I.N. and Olayinka, J.N. (2016) Antibacterial activity of Moringa oleifera Lam leaves on enteric human pathogens. Indian J. Appl. Res., 6(8): 553-557. 